\title{
Rainfall stimulation of primary production in western Atlantic Ocean waters: roles of different nitrogen sources and co-limiting nutrients
}

\author{
Hans W. Paerl ${ }^{1, *}$, Joan D. Willey ${ }^{2}$, Malia Go ${ }^{1}$, Benjamin L. Peierls ${ }^{1}$, \\ James L. Pinckney ${ }^{3}$, Marilyn L. Fogel ${ }^{4}$ \\ ${ }^{1}$ University of North Carolina at Chapel Hill, Institute of Marine Sciences, 3431 Arendell Street, Morehead City, \\ North Carolina 28557, USA \\ ${ }^{2}$ University of North Carolina, Wilmington, Department of Chemistry and Marine Science Program, Wilmington, \\ North Carolina 28403-3297, USA \\ ${ }^{3}$ Texas A \& M University, Department of Oceanography, College Station, Texas 77843-3146, USA \\ ${ }^{4}$ Carnegie Institution of Washington, Geophysical Laboratory, Washington, DC 20015, USA
}

\begin{abstract}
Using shipboard bioassays, we examined the roles rainfall, individual and combined nutrients play in accelerating primary production in coastal, Gulf Stream and pelagic (Sargasso Sea) locations in the North Atlantic Ocean off North Carolina, USA, from 1993 to 1995. Photosynthetic $\mathrm{CO}_{2}$ fixation and net chlorophyll a (chl a) production were measured in replicated bioassays to assess individual and combined impacts of different constituents of atmospheric deposition, including natural rainfall, a synthetic rain mix, dissolved inorganic nitrogen (DIN $\mathrm{NH}_{4}{ }^{+}, \mathrm{NO}_{3}{ }^{-}$), dissolved organic nitrogen (DON, urea), phosphorus $\left(\mathrm{PO}_{4}{ }^{3-}\right.$ ) and iron (as EDTA-chelated and unchelated $\mathrm{FeCl}_{3}$ ). Natural rainfall and DIN additions most often stimulated $\mathrm{CO}_{2}$ fixation and chl a production, but frequencies and magnitudes of biostimulation, relative to controls, varied between these indicators. Spatial differences in the types and magnitudes of stimulation were also observed. When added in equimolar amounts, $\mathrm{NH}_{4}$ " was, at times, more stimulatory than $\mathrm{NO}_{3}^{-}$. The $\mathrm{NO}_{3}^{-}$stimulation was significantly enhanced by Fe-EDTA. Urea was marginally stimulatory at the coastal location. $\mathrm{PO}_{4}{ }^{3-}$ was never stimulatory. Fe-EDTA and EDTA by themselves stimulated production only at the offshore locations, suggesting increased Fe limitation with increasing distance from land. Synthetic rain, which contained both sources of DIN, but not $\mathrm{Fe}$, generally proved less stimulatory per unit $\mathrm{N}$ than natural rainfall. Results indicate a broad sensitivity of these waters to $\mathrm{N}$ additions, which in the case of $\mathrm{NO}_{3}{ }^{-}$are enhanced by Fe-EDTA. At all locations, the high level of stimulation of primary production attributable to natural rain may be due to the supply of both DIN and co-limiting nutrients (e.g. Fe), contributing to the eutrophication potential of waters downwind of urban, industrial and agricultural emissions.
\end{abstract}

KEY WORDS: Atmospheric deposition - Nitrogen - Iron - Primary production - Eutrophication W. Atlantic Ocean

\section{INTRODUCTION}

Nitrogen (N) supply frequently limits primary production in coastal waters (Dugdale 1967, Ryther \& Dunstan 1971, Nixon 1986) and together with iron (Fe) plays an important role in controlling production in pelagic areas distant from land (Dugdale 1967, Martin et al. 1994). This common finding has fostered exten-

•E-mail: hans_paerl@unc.edu sive research evaluating the roles that externally supplied, 'new' $\mathrm{N}$ inputs play in accelerating primary production and eutrophication of $\mathrm{N}$-sensitive waters. One source of 'new' $N$ is atmospheric deposition (AD) of anthropogenically produced $\mathrm{N}$ compounds, which has recently been recognized as a significant and growing fraction of external N loading (Paerl 1985, 1993, Duce 1986). Approximately 20 to $40 \%$ of 'new' $N$ inputs into coastal waters downwind of continental regions are of atmospheric origin (Martin et al. 1989, Loye-Pilot et al. 
1990, Prado-Fiedler 1990, Paerl 1993, 1995), much of it due to growing agricultural, urban and industrial emissions (Briblecombe \& Stedman 1982, Rodhe \& Rood 1986, Buijsman et al. 1987, Galloway et al. 1994). The relative contribution of $\mathrm{AD}-\mathrm{N}$ to coastal $\mathrm{N}$ budgets will increase substantially as we enter the next century, when nearly $70 \%$ of the European and North American populations will reside within $50 \mathrm{~km}$ of the coast (Galloway et al. 1994). On regional and global scales, AD-N is a significant contributor to oceanic 'new' $\mathrm{N}$ inputs, accounting for $\sim 35 \mathrm{Tg} \mathrm{N} \mathrm{yr}{ }^{-1}$, compared to $30 \mathrm{Tg} \mathrm{N} \mathrm{yx^{-1 }}$ from riverine discharge, 5 to $10 \mathrm{Tg} \mathrm{N} \mathrm{yr}^{-1}$ from groundwater and $\sim 8 \mathrm{Tg} \mathrm{N} \mathrm{yr}^{-1}$ from biological nitrogen fixation (Wollast 1991, Codispoti et al. in press). Atmospheric N is particularly important to surface seawater productivity because, unlike river discharge, AD-N does not pass through the 'estuarine filter' (Kennedy 1986), but rather is directly deposited on the sea surface.

Both wet and dry forms of AD contain various biologically reactive $\mathrm{N}$ compounds. In addition to the inorganic forms $\mathrm{NH}_{3} / \mathrm{NH}_{4}{ }^{+}, \mathrm{NO}_{2}^{-}, \mathrm{NO}_{3}{ }^{-}$, there are organic $\mathrm{N}$ compounds such as urea, amino acids and organonitrates (Timperley et al. 1985, Duce 1986, Mopper \& Zika 1987, Cornell et al. 1995, Peierls \& Paerl 1997). Stimulation of marine primary production by these sources has been evaluated in bioassay-based studies spanning $\mathrm{N}$-limited estuarine, coastal and oceanic ecosystems (Thayer 1974, Paerl et al. 1990, Willey \& Cahoon 1991, Willey \& Paerl 1993, Paerl \& Fogel 1994, Peierls \& Paerl 1997). While dissolved inorganic $N$ (DIN) compounds in rainfall have been clearly shown to stimulate primary production (Paerl 1985, Paerl et al. 1990), these studies also suggested that some factor(s) other than DIN play a biostimulatory role. For example, Paerl et al. (1990) and Paerl \& Fogel (1994) noted that, per amount of $\mathrm{N}$, rainfall. produced more stimulation than either $\mathrm{NH}_{4}{ }^{+}$or $\mathrm{NO}_{3}^{-}$additions.

Suggested potential 'missing factors' include nutrient trace metals and dissolved organic N (DON) (Paerl \& Fogel 1994). Recently, Peierls \& Paerl (1997) examined the bioreactivity of DON fractions in rainfall. DON proved stimulatory to nearshore phytoplankton, but at magnitudes far less than DIN. Moreover, DON compounds previously identified in rainfall (urea, amino acids) failed to enhance production of offshore oligotrophic phytoplankton communities. Therefore, factors in addition to DIN and DON may cause the potent fertilizing impact of rainfall, and the role of aerosol trace nutrients is considered here.

Continental dust (e.g. Saharan soil dust, volcanic, urban and industrial particulate emissions) can be deposited on the sea surface as dry deposition, or incorporated into rain by washout and deposited as wet deposition (Church et al. 1984, Duce \& Tindale 1991). The amount of soil dust in the atmosphere may increase as a result of expanded agricultural practices, which would increase crustal elements in $\mathrm{AD}$, including Al, Fe, Si and P (Duce et al. 1991). Certain crustal elements including $\mathrm{Fe}$ may increase in solubility in aerosols as a result of photoreduction (Behra \& Sigg 1990, Zhuang et al. 1992, 1995) and repeated exposure to acidic cloudwater (Spokes et al. 1994, Jickells 1995). Aerosols from anthropogenic sources, including combustion processes, may also increase as a result of industrial growth. Trace metals, including $\mathrm{Cd}, \mathrm{Pb}$, $\mathrm{Zn}, \mathrm{Cu}, \mathrm{Ni}$ and $\mathrm{V}$, are thought to be elevated in rain relative to crustal concentrations (Church et al. 1984). Rain is thus a delivery mechanism for many trace metals, and provides a solubility-enhancing environment for some of them (Duce \& Tindale 1991, Duce et al. 1991).

Among nutrient trace metals in continentally derived $\mathrm{AD}$, Fe has been shown to be a stimulant of marine primary production (Martin et al. 1994). AD is the primary source of new iron to the oceans (Duce 1986, Duce \& Tindale 1991), and Fe has been shown to enhance marine primary production in geographically diverse oceanic waters (Martin et al. 1991, 1994, DiTullio et al. 1993, Takeda et al. 1995). Stimulation was maximal in the presence of $\mathrm{N}$ (as $\mathrm{NO}_{3}{ }^{-}$) enrichment. Likewise, Paerl et al. (1994) demonstrated that growth and $\mathrm{N}_{2}$ fixation of the bloom-forming, planktonic cyanobacterium Trichodesmium spp. were enhanced by Fe additions in $\mathrm{N}$-depleted coastal and nearshore Allantic Ocean (Gulf Stream) waters.

The enzymes responsible for $\mathrm{NO}_{3}{ }^{-}$reduction to $\mathrm{NH}_{3}$ (nitrite and nitrate reductases) and $\mathrm{N}_{2}$ fixation (nitrogenase) contain Fe (Stewart 1974). Therefore, phytoplankton relying on these new $N$ compounds have relatively high requirements for this metal, and under conditions of $\mathrm{NO}_{3}^{-}$enrichment $\mathrm{Fe}$ requirements for synthesis of these enzymes are high. Continentally derived rainfall and dryfall are enriched with $\mathrm{N}$ (DIN $\approx$ 20 to $>50 \mu \mathrm{M}$, mostly as $\mathrm{NO}_{3}{ }^{-} ; \mathrm{DON} \approx 5$ to $20 \mu \mathrm{M}$ ), and $N$ enrichment from this source may increase the potential for Fe limitation, which in turn could control new production, f-ratios and phytoplankton community composition (Harrison et al. 1987). This scenario is most applicable to pelagic waters, where iron availability is often severely restricted and aeolian inputs are the sole source of new Fe (Martin et al. 1994)

In eastern North Carolina, riverine inputs are small, and nutrients are effectively assimilated by estuarine and coastal sound phytoplankton communities. This leads to relatively low levels of 'new' nutrient discharge into coastal and oceanic waters by rivers (Copeland \& Gray 1991), and suggests that atmospheric and advective (upwelling/deep mixing) nutrient inputs may be key sources of 'new' nutrients supporting primary production. The proximity and 
predominantly downwind location of oligotrophic Gulf Stream and Sargasso Sea surface waters to the North American continent further suggest that atmospheric deposition may be very important as a source of multiple, synergistically interacting nutrients to this oceanic region. In the present paper we investigate the possibility that $\mathrm{Fe}$ may play a key synergistic role in the observed potent (based on $\mathrm{N}$ alone) fertilizing capability of AD.

\section{MATERIALS AND METHODS}

Sampling locations. The impacts of rainfall were compared with individual and combined $\mathrm{N}$ and $\mathrm{Fe}$ enrichments in North Carolina nearshore and offshore western North Atlantic waters previously documented as being $N$ limited (Paerl 1985, Paerl et al. 1990). Transects $(\sim 200 \mathrm{~km})$ of nearshore to offshore locations were sampled at 3 locations during 5 cruises of the RV 'Cape Hatteras' from 1993 to 1995. The nearshore (inner continental shelf) location was approximately $25 \mathrm{~km}$ SE of Beaufort, North Carolina (Fig. 1); an offshore location was near the western boundary of the Gulf Stream, ranging from 60 to $100 \mathrm{~km}$ offshore. A third oceanic station was located well beyond the eastern boundary of the Gulf Stream in the Sargasso Sea, approximately 150 to $200 \mathrm{~km}$ SE of Beaufort. These locations were sampled on 5 occasions between 1993 and 1995, during late spring (May to June) and fall (September to November).

Experimental procedures. Seawater was collected at $1.5 \mathrm{~m}$ depth with a non-metallic (PVC-lined) diaphragm pump attached to natural rubber hoses, which were flushed for several hours prior to dispensing seawater into polyethylene Cubitainers for nutrient addition bioassays. The Cubitainers were first rinsed with $1 \% \mathrm{HCl}$, followed by exhaustive seawater (from each sampling location) rinses prior to filling. Both 1 and 41 Cubitainers were used as bioassay vessels, the former for ${ }^{14} \mathrm{C}$-based measurements of photosynthesis and the latter for chlorophyll a ( $\mathrm{chl}$ a)-based determinations of biomass. Cubitainers are chemically inert and approximately $80 \%$ transparent to photosynthetically active radiation (PAR: 400 to $700 \mathrm{~nm}$ ) (Paerl et al. 1990). Each 1 l Cubitainer was supplied with $900 \mathrm{ml}$ seawater including nutrient or rain additions, while the 41 vessels contained 3.5 l seawater. Six unamended controls were run in parallel with treatments. Experimental treatments were run in triplicate. We examined impacts of nutrients previously implicated in the control of primary production in these waters. These included: DIN $\left(\mathrm{NH}_{4}^{+}, \mathrm{NO}_{3}{ }^{-}\right), \mathrm{DON}$ (urea), phosphorus $\left(\mathrm{PO}_{4}{ }^{3-}\right)$ and $\mathrm{Fe}$ (equimolar EDTA-chelated and unchelated $\mathrm{FeCl}_{3}$ ). Prior work (Paerl et al. 1990, Rudek et al. 1991) indicated silicon (Si) sufficiency under a range of N, P and

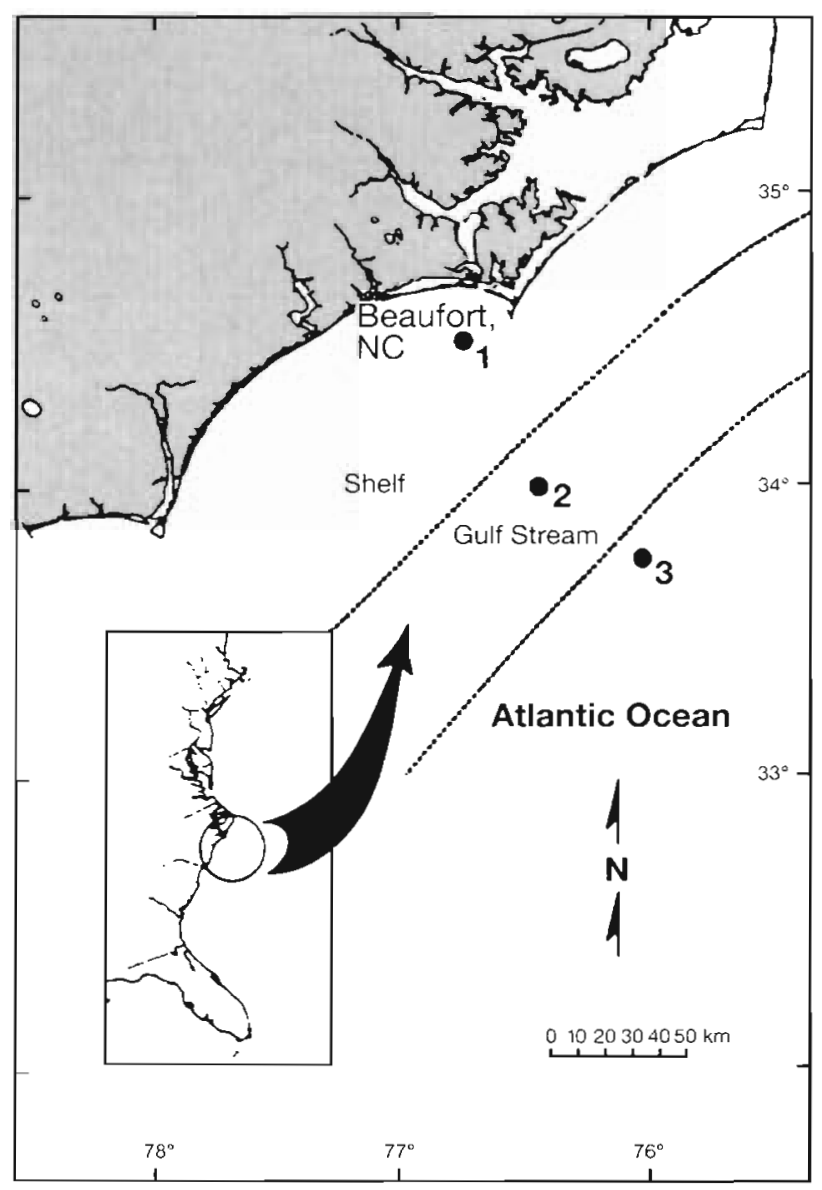

Fig. 1. Nutrient/rain addition bioassay locations sampled 1993 to 1995 during cruises of the RV 'Cape Hatteras' in the western Atlantic Ocean, off North Carolina, USA.

trace metal enrichment conditions. Treatments and nutrient additions are shown in Table 1.

All nutrient and rain additions were dispensed from polyethylene (Nalgene) bottles. Fe and EDTA solutions were freshly mixed and stored in Teflon containers and dispensed with polyethylene pipette tips cleaned with $1 \% \mathrm{HCl}$ and $18 \mathrm{M} \Omega$ deionized water. Reagents were analytical grade. In the case of Fe salts (Fisher), ultrapure reagent grades were used. The EDTA used was supplied and shown to be essentially free of Fe by Dr K. Bruland, University of California, Santa Cruz. Efforts were made to ensure 'clean techniques' throughout bioassay procedures.

Rainwater was collected with precleaned polyethylene funnels and carboys on the laboratory rooftop (Morehead City, North Carolina, USA) during storms prior to the bioassays. Precleaning included a $1 \% \mathrm{HCl}$ rinse followed by several rinses of $18 \mathrm{M} \Omega$ deionized water. Nutrient $\left(\mathrm{NO}_{2}{ }^{-} / \mathrm{NO}_{3}{ }^{-}, \mathrm{NH}_{4}{ }^{+}\right.$, organic $\left.\mathrm{N}, \mathrm{PO}_{4}{ }^{3-}\right)$ content of the rainwater was determined. If not used immediately, rainwater was stored frozen $\left(-20^{\circ} \mathrm{C}\right)$ in carboys 
Table 1 Rainwater and nutrient additions in Cubitainer bioassays

\begin{tabular}{|c|c|}
\hline Treatment & Final concentrations/comments \\
\hline Control & No rain/nutrients added \\
\hline Natural rain & $\begin{array}{l}1-3 \% \mathrm{v} / \mathrm{v} \text { additions, } \\
3 \% \text { in most bioassays }\end{array}$ \\
\hline Synthetic rain & $\begin{array}{l}1-3 \% \mathrm{v} / \mathrm{v} \text { additions, } \\
3 \% \text { in most bioassays }\end{array}$ \\
\hline $\mathrm{NO}_{3}{ }^{-}-\mathrm{N}\left(\mathrm{as} \mathrm{NaNO}_{3}\right)$ & $5 \mu \mathrm{M}$ \\
\hline $\mathrm{NH}_{4}{ }^{+}-\mathrm{N}\left(\right.$ as $\left.\mathrm{NH}_{4} \mathrm{Cl}\right)$ & $5 \mu \mathrm{M}$ \\
\hline Urea-N & $5 \mu \mathrm{M}$ \\
\hline $\mathrm{PO}_{4}^{3--}-\mathrm{P}\left(\right.$ as $\left.\mathrm{NaH}_{2} \mathrm{PO}_{4}\right)$ & $2 \mu \mathrm{M}$ \\
\hline $\mathrm{Fe}^{3+}\left(\right.$ as $\left.\mathrm{FeCl}_{3}\right)$ & $0.05-1 \mu \mathrm{M}$ \\
\hline EDTA (as $\left.\mathrm{Na}_{2} \mathrm{EDTA}\right)$ & $0.05-1 \mu \mathrm{M}$ \\
\hline $\mathrm{FeCl}_{3}+\mathrm{EDTA}$ & $0.2+0.2 \mu \mathrm{M}$ \\
\hline $\mathrm{FeCl}_{3}+\mathrm{EDTA}+\mathrm{NO}_{3}^{-}$ & $0.2+0.2+5 \mu \mathrm{M}$ \\
\hline
\end{tabular}

and reanalyzed for nutrient concentrations shortly before use in bioassays. During 1994, we encountered an event of heavy rainfall containing $125 \mu \mathrm{M} \mathrm{NH}_{4}{ }^{+}$This event, termed 'high $\mathrm{NH}_{4}{ }^{{ }^{\prime}}$, was used in the May 1994 biossays. The final DIN $\left(\mathrm{NH}_{4}{ }^{+}+\mathrm{NO}_{2}{ }^{-} / \mathrm{NO}_{3}{ }^{-}\right)$concentration after natural rain additions ranged from 2.1 to $3.1 \mu \mathrm{M} \mathrm{N}$ respectively, while the high $\mathrm{NH}_{4}{ }^{+}$natural rain addition resulted in a final concentration of $4.8 \mu \mathrm{MN}$.

The synthetic rainwater composition was $20 \mu \mathrm{M}$ $\mathrm{HNO}_{3}, 5 \mu \mathrm{M} \mathrm{NH}_{4}^{+}$as $\left(\mathrm{NH}_{4}\right)_{2} \mathrm{SO}_{4}$, and $20 \mu \mathrm{M} \mathrm{H}_{2} \mathrm{SO}_{4}$ in $18 \mathrm{M} \Omega$ deionized water $(\mathrm{pH}=4.25)$. The composition of the synthetic rain was checked for $\mathrm{pH}$ by lowconductivity probes and by ion chromatography before and after each bioassay.

Seawater, rainwater and nutrients were added to Cubitainers with Nalgene polyethylene graduated cylinders or autopipetted using precleaned polyethylene or polypropylene tips. The $1 \mathrm{l}$ Cubitainers received $7.5 \mu \mathrm{Ci}$ of ${ }^{14} \mathrm{C}-\mathrm{Na}$ bicarbonate $\left(60 \mathrm{mCi} \mathrm{mmol}^{-1}\right.$; ICN Inc.) for determining photosynthetic $\mathrm{CO}_{2}$ fixation. Following additions, Cubitainers were sealed and transported to on-deck plastic wading pools filled with circulating seawater, exposed to natural irradiance and temperatures. Previous time-course studies using Cubitainers (Paerl et al. 1990, Rudek et al. 1991) indicated that for these waters optimal growth yields were obtained within 2 to $3 \mathrm{~d}$ following nutrient additions. Longer incubation periods could lead to methodological artifacts, including fouling of the vessels, dissolved inorganic carbon depletion and grazing impacts. On sunny days, 1 layer of neutral density screening (reducing incident irradiance by $30 \%$ ) was placed over pools to minimize photoinhibition and photooxidation of natural phytoplankton communities. The ship's motion ensured continual mixing of cubitainers.

For ${ }^{14} \mathrm{C}$ fixation measurements, the entire $900 \mathrm{ml}$ in 11 Cubitainers was vacuum filtered $(200 \mathrm{~mm} \mathrm{Hg})$ through $25 \mathrm{~mm}$ Whatman GF/F filters (approximate pore size $=0.4 \mu \mathrm{m}$ ). Filters were air dried, fumed with $\mathrm{HCl}$ vapors for $2 \mathrm{~h}$, air dried again, placed in $7 \mathrm{ml}$ of Ecolume cocktail (ICN Inc.) and analyzed by liquid scintillation spectrometry (Beckman LS 7500) (Paerl 1987). The entire $3.5 \mathrm{l}$ in each large Cubitainer was filtered onto a $4.8 \mathrm{~cm}$ GF/F filter which was subsequently analyzed for chl a by fluorometry using a Turner Model 110 fluorometer (Strickland \& Parsons 1972). Initial dissolved inorganic $N$ and $P$ concentrations were determined on GF/F filtered and frozen subsamples from all waters assayed. Nutrients were subsequently analyzed using a high sensitivity autoanalyzer following the manufacturer's instructions (Lachat Quick Chem. IV, Lachat Instruments, Milwaukee, Wisconsin, USA; $\mathrm{NH}_{4}^{+}$, Method 31-107-06-1-A; $\mathrm{NO}_{2}{ }^{-} / \mathrm{NO}_{3}{ }^{-}, 31-107-04-1-\mathrm{C} ; \mathrm{PO}_{4}{ }^{3-}, 31-115-01-3-\mathrm{A}$ ).

Rainwater was not analyzed for Fe content because of difficulties in ensuring trace metal free conditions in such determinations. Instead, we referred to the rain iron concentration data of Church et al. (1984) from Lewes, Delaware, USA $(0.27 \mu \mathrm{M})$ and Bermuda (0.09 $\mu \mathrm{M})$, and from Church et al. (1991) for oceanic rain (from 0.1 to $0.5 \mu \mathrm{M}$ ) to plan our experiments. Fe concentrations of ambient surface seawater were not measured; concentrations were most likely in the nanomolar to subnanomolar range (Powell et al. 1995, Zhuang et al. 1995). The amount of iron added was chosen to give an excess of at least 10 times ambient quantities. This concentration is below the solubility of iron in the presence of EDTA in seawater. Rainwater analyses of dissolved organic carbon (DOC) (University of North Carolina at Wilmington) during summer 1996 indicate that DOC varied from 30 to $500 \mu \mathrm{M}$, with an average of approximately $300 \mu \mathrm{M}$. This suggests that at least some of the iron in rain may be organically complexed, which makes addition of iron as the EDTA complex more realistic.

All bioassay responses were examined relative to the control. Productivity responses of the phytoplankton community measured as ${ }^{14} \mathrm{CO}_{2}$ fixation or chl a content were compared statistically for each bioassay using an a posteriori comparison of means procedure (Bonferroni, $p<0.05$ ). Values were natural $\log (\ln )$ transformed before analysis to normalize the data.

\section{RESULTS}

\section{Ambient nutrients}

Ambient nutrient concentrations at all locations and all dates proved to be uniformly low and near the limit of detection. For $\mathrm{NO}_{3}{ }^{-} \mathrm{NO}_{2}{ }^{-}-\mathrm{N}$, ambient concentrations were between 0.02 and $0.3 \mu \mathrm{M}$, with springtime (May 1994. May 1995) concentrations tending to be 
higher. The one exception followed Hurricane Gordon (November 1994), when extensive vertical mixing introduced $0.5-0.9 \mu \mathrm{M}$ to surface waters. Ammonium $\left(\mathrm{NH}_{4}{ }^{+}-\mathrm{N}\right)$ concentrations were consistently $<0.2 \mu \mathrm{M}$ on all sampling dates at all locations. After the passage of Hurricane Gordon $\mathrm{NH}_{4}{ }^{+}$levels were slightly elevated $(0.4$ to $0.6 \mu \mathrm{M})$ in the upper water column at all three locations. The DIN enrichment resulting from Hurricane Gordon caused increases in both primary production and chl a concentrations of impacted waters (Fogel et al. in press). Orthophosphate $\left(\mathrm{PO}_{4}{ }^{3-}-\mathrm{P}\right)$ concentrations ranged from 0.2 to $0.7 \mu \mathrm{M}$ at all locations and dates, with slighty higher values $(0.5$ to $1.2 \mu \mathrm{M})$ following Hurricane Gordon.

\section{Bioassays}

Among bioassay treatments, individual $\mathrm{N}$ and natural and synthetic rainfall additions proved most stim- ulatory to $\mathrm{CO}_{2}$ fixation and chl a production. Substantial variation in the frequencies and magnitudes of stimulation, relative to controls, was observed among sampling locations throughout the sampling period. On occasions, natural rainfall proved more stimulatory than synthetic rain (Table 2 ). When rainfall contained relatively high $\mathrm{NH}_{4}{ }^{+}$concentrations $(4.8 \mu \mathrm{M} \mathrm{N}$ final concentration in May 1994), both $\mathrm{CO}_{2}$ fixation and chl a showed the highest magnitudes of stimulation, which were most significant at the inner shelf location (Table 2, Fig. 2). While rainfall additions did not yield statistically significant impacts on production at the Gulf Stream and Sargasso Sea locations during 1994 (due to large standard deviation values relative to absolute ${ }^{14} \mathrm{CO}_{2}$ fixation and chl a values among replicates at these locations), stimulation relative to controls was routinely observed during the experiments conducted in the present study. When taking all locations and dates into consideration, natural rainfall stimulated production from 136 to over $400 \%$, while syn-

Table 2. Summary of treatment effects (chl a and production) of nutrient amendments by cruise date and location; +: treatment mean was significantly higher than the control ( $\mathrm{p}<0.05$, Bonferroni a posteriori comparisons of means); magnitudes (in \%) of stimulation are shown. (nd: response not determined; ns: mean not significantly different from control). May 1994 natural rain contained elevated $\mathrm{NH}_{4}{ }^{+}$

\begin{tabular}{|c|c|c|c|c|c|c|c|c|c|c|c|}
\hline \multirow{2}{*}{ Treatment } & \multirow{2}{*}{$\begin{array}{l}\text { Concen- } \\
\text { tration }\end{array}$} & \multicolumn{2}{|c|}{ Nov 1993} & \multicolumn{2}{|c|}{ May 1994} & \multicolumn{2}{|c|}{ Nov 1994} & \multicolumn{2}{|c|}{ May 1995} & \multicolumn{2}{|c|}{ Sep 1995} \\
\hline & & Chl a & Prod. & $\mathrm{Chla}$ & Prod. & Chl a & Prod. & Chl a & Prod. & Chl a & Prod. \\
\hline \multicolumn{12}{|l|}{ Inner shelf } \\
\hline Synthetic rain & $3 \%$ & ns & ns & +211 & +247 & ns & +124 & +163 & ns & +267 & +164 \\
\hline Natural rain & $3 \%$ & ns & +182 & +239 & +260 & ns & +136 & +232 & ns & +471 & +168 \\
\hline Nitrate & $5 \mu \mathrm{M}$ & +129 & ns & ns & ns & ns & ns & +310 & +360 & +318 & ns \\
\hline Ammonium & $5 \mu \mathrm{M}$ & ns & ns & ns & ns & ns & ns & +400 & +475 & +321 & +286 \\
\hline Phosphate & $2 \mu \mathrm{M}$ & ns & ns & ns & ns & ns & ns & ns & ns & ns & ns \\
\hline Ferric chloride & $0.2 \mu \mathrm{M}$ & $\mathrm{ns}$ & ns & ns & ns & ns & ns & ns & ns & ns & ns \\
\hline EDTA & $0.2 \mu \mathrm{M}$ & \multicolumn{2}{|c|}{- nd -} & ns & ns & ns & ns & ns & ns & ns & ns \\
\hline $\mathrm{FeCl}+\mathrm{EDTA}$ & & ns & ns & ns & ns & ns & ns & ns & ns & \multicolumn{2}{|c|}{$-n d-$} \\
\hline $\mathrm{FeCl}+$ EDTA + Nitrate & & +169 & +162 & +302 & +283 & ns & +198 & +318 & ns & +276 & +192 \\
\hline Urea & $5 \mu \mathrm{M}$ & ns & ns & $\mathrm{ns}$ & +141 & ns & ns & ns & ns & +354 & +186 \\
\hline \multicolumn{12}{|l|}{ Gulf Stream } \\
\hline Synthetic rain & $3 \%$ & $\mathrm{~ns}$ & ns & ns & ns & ns & ns & +267 & ns & +200 & ns \\
\hline Natural rain & $3 \%$ & ns & ns & ns & ns & ns & ns & +475 & +347 & ns & +143 \\
\hline Nitrate & $5 \mu \mathrm{M}$ & ns & ns & ns & ns & ns & ns & +405 & ns & ns & ns \\
\hline Ammonium & $5 \mu \mathrm{M}$ & ns & ns & ns & ns & ns & ns & +466 & +248 & ns & +280 \\
\hline Phosphate & $2 \mu \mathrm{M}$ & ns & ns & ns & ns & ns & ns & ns & ns & ns & ns \\
\hline Ferric chloride & $0.2 \mu \mathrm{M}$ & ns & ns & ns & ns & ns & ns & +367 & ns & \multicolumn{2}{|c|}{- nd - } \\
\hline EDTA & $0.2 \mu \mathrm{M}$ & \multicolumn{2}{|c|}{- nd - } & +320 & +349 & $\mathrm{~ns}$ & +242 & +567 & ns & +260 & +225 \\
\hline $\mathrm{FeCl}+\mathrm{EDTA}$ & & ns & ns & +354 & +338 & +147 & +186 & +267 & ns & ns & ns \\
\hline $\mathrm{FeCl}+\mathrm{EDTA}+$ Nitrate & & ns & ns & +440 & +320 & +159 & +252 & +400 & +256 & ns & +238 \\
\hline Urea & $5 \mu \mathrm{M}$ & ns & ns & ns & ns & ns & ns & ns & ns & +220 & ns \\
\hline \multicolumn{12}{|l|}{ Sargasso Sea } \\
\hline Synthetic rain & $3 \%$ & ns & ns & \multicolumn{2}{|c|}{- nd -} & n15 & +195 & & & & \\
\hline Natural rain & $3 \%$ & ns & +220 & \multicolumn{2}{|c|}{$-n d-$} & ns & +221 & & & & \\
\hline Nitrate & $5 \mu \mathrm{M}$ & ns & ns & +180 & +140 & ns & ns & & & & \\
\hline Ammonium & $5 \mu \mathrm{M}$ & ns & ns & +186 & +155 & ns & ns & & & & \\
\hline Phosphate & $2 \mu \mathrm{M}$ & ns & ns & ns & ns & ns & ns & & & & \\
\hline Ferric chloride & $0.2 \mu \mathrm{M}$ & ns & ns & ns & +133 & ns & ns & & & & \\
\hline EDTA & $0.2 \mu \mathrm{M}$ & \multicolumn{2}{|c|}{$-\mathrm{nd}-$} & ns & +187 & ns & +218 & & & & \\
\hline $\mathrm{FeCl}+\mathrm{EDTA}$ & & ns & +231 & ns & +190 & ns & ns & & & & \\
\hline $\mathrm{FeCl}+$ EDTA + Nitrate & & +235 & +224 & +235 & +195 & +240 & +224 & & & & \\
\hline Urea & $5 \mu \mathrm{M}$ & ns & ns & \multicolumn{2}{|c|}{$-\mathrm{nd}-$} & ns & ns & & & & \\
\hline
\end{tabular}



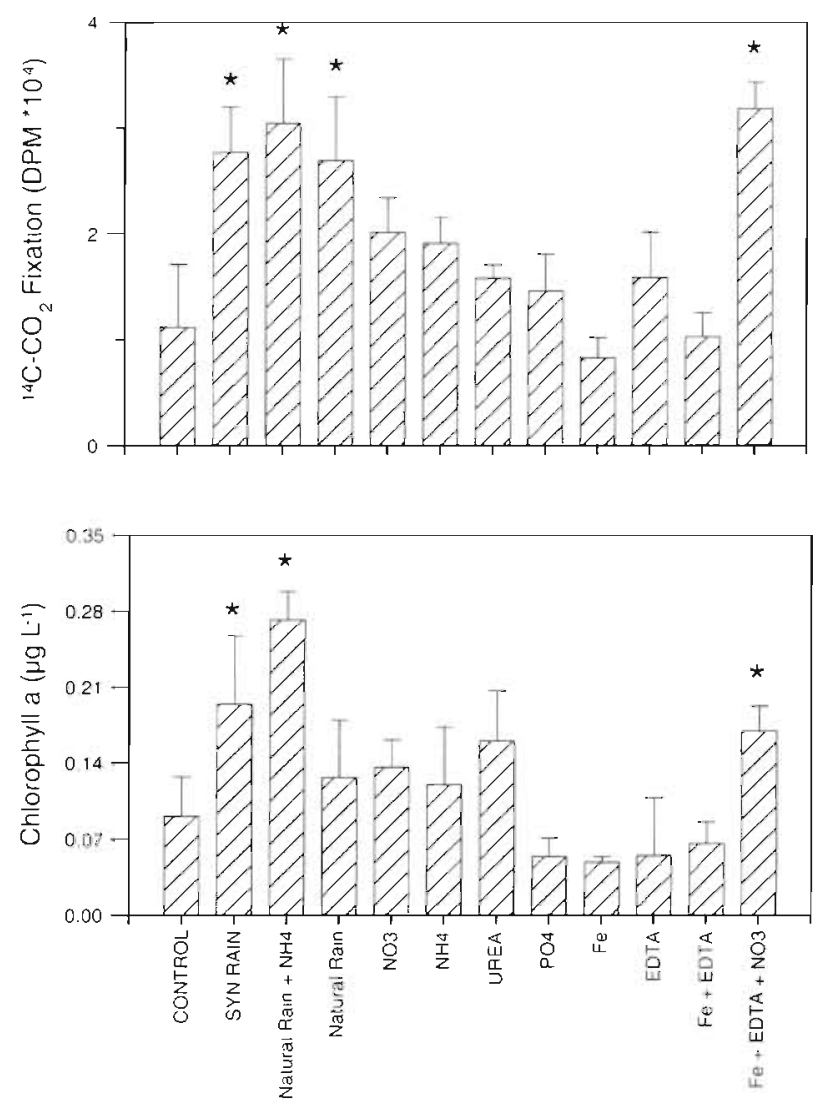

Fig. 2. Bioassays of productivity responses, shown as both ${ }^{14} \mathrm{CO}_{2}$ fixation (disintegrations per minute, DPM, upper panel) and chl a concentrations (lower panel), of coastal Atlantic Ocean phytoplankton assemblages to a variety of rainfall and nutrient additions in May 1994. Nutrient additions are shown in Table 1. Final DIN $\left(\mathrm{NH}_{4}{ }^{+}+\mathrm{NO}_{2}{ }^{-} / \mathrm{NO}_{3}{ }^{-}\right)$concentration in the natural rain addition was $2.8 \mu \mathrm{M} \mathrm{N}$, while the high $\mathrm{NH}_{4}{ }^{+}$natural rain addition resulted in a final concentration of $4.8 \mu \mathrm{M}$ $\mathrm{N}$. Treatments are plotted relative to the control, with $\pm 1 \mathrm{SD}$ shown. Treatments that were significantly different from controls are indicated by an asterisk. ' $\mathrm{Fe}$ ' indicates unchelated $\mathrm{FeCl}_{3}$. Bioassays were incubated for $2 \mathrm{~d}$

thetic rain stimulated from 124 to over $260 \%$ (Table 2). DIN additions, either as $\mathrm{NH}_{4}{ }^{+}$or $\mathrm{NO}_{3}{ }^{-}$, stimulated $\mathrm{CO}_{2}$ fixation and chl a significantly in 50 and $40 \%$ of the inner shelf bioassays respectively throughout the study period (Table 2). The degree of significant $\mathrm{NH}_{4}{ }^{+}$or $\mathrm{NO}_{3}{ }^{-}$stimulation to ${ }^{14} \mathrm{C}-\mathrm{CO}_{2}$ fixation and chl a production was slightly less for the Gulf Stream and Sargasso Sea locations.

The numbers of significant DIN stimulation events were higher in 1995 than 1993 or 1994; this difference was largely attributable to large standard deviation values relative to absolute ${ }^{14} \mathrm{CO}_{2}$ fixation and chl a values in 1993 and 1994. In general, productivity responses to nutrient additions in 1995 were higher than in previous years, leading to larger and more significant differences between controls and treatments.
No strong seasonal (i.e. spring vs fall within any single year) trends were observed at any of the locations for either ${ }^{14} \mathrm{CO}_{2}$ fixation or chl a. The magnitudes of rainfall-based DIN stimulation varied spatially and temporally. Some of the observed variation may be attributed to differential DIN or DON content of either the rainfall or receiving waters and contrasting phytoplankton assemblages in diverse water masses during the experimental period (cf. Paerl 1985, Paerl et al. 1990, Paerl \& Fogel 1994, Peierls \& Paerl 1997). At times, natural and synthetic rain additions also led to different magnitudes of stimulation, despite yielding comparable final DIN levels (i.e. ambient + added DIN, Figs. 2, $3 \& 4$ ), suggesting that factors other than just DIN content played a role in the observed biostimulation. In $40 \%$ of all bioassays, $\mathrm{NH}_{4}{ }^{+}$and $\mathrm{NO}_{3}{ }^{-}$both significantly stimulated production, when added as similar amounts of $\mathrm{N}$ (Table 2). At times, however, $\mathrm{NH}_{4}{ }^{+}$enrichment led to greater and more significant stimulation than $\mathrm{NO}_{3}^{-}$; this was most noticeable at the Gulf Stream location where significant differences were especially evident in ${ }^{14} \mathrm{CO}_{2}$ fixation bioassays conducted in May and September, 1995 (Table 2).

$\mathrm{FeCl}_{3}$ alone generally failed to significantly stimulate either ${ }^{14} \mathrm{CO}_{2}$ fixation or chl a (Figs 2, $3 \& 4$, Table 2). In contrast, EDTA and $\mathrm{FeCl}_{3}+$ EDTA often stimulated

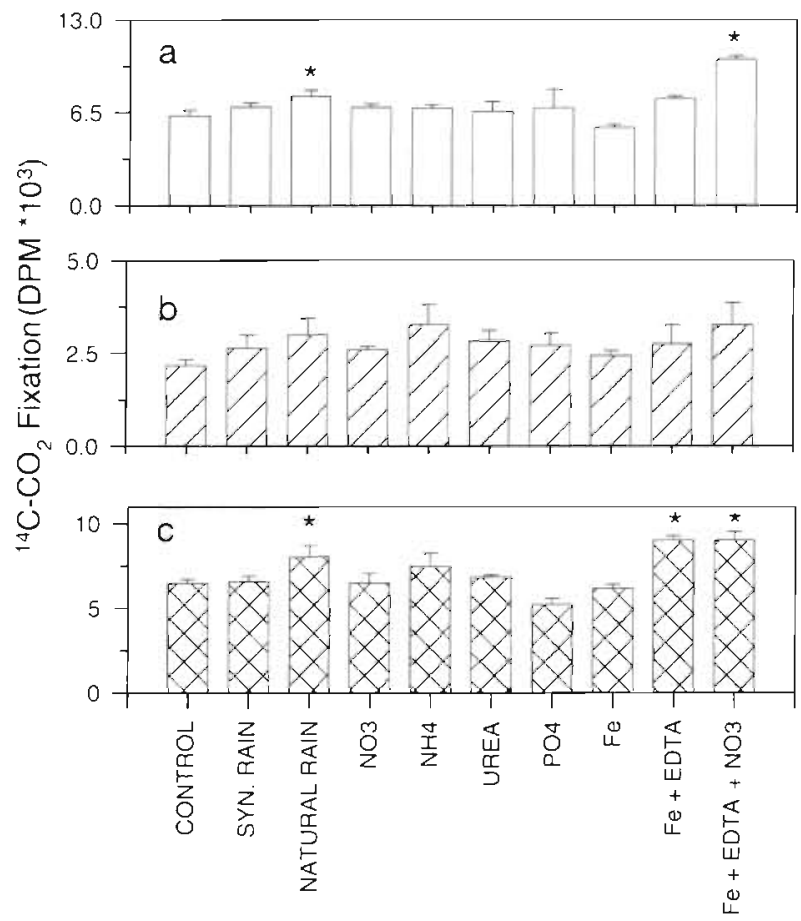

Fig. 3. Phytoplankton ${ }^{14} \mathrm{CO}_{2}$ fixation responses to nutrient and synthetic and natura! rain additions at (a) inner shelf, (b) Gulf Stream and (c) Sargasso Sea locations during November 1993. The same natural rain event $(2.1 \mu \mathrm{M}$ final DIN concentration) was added at all locations. Bioassays were incubated for $2 \mathrm{~d}$ 

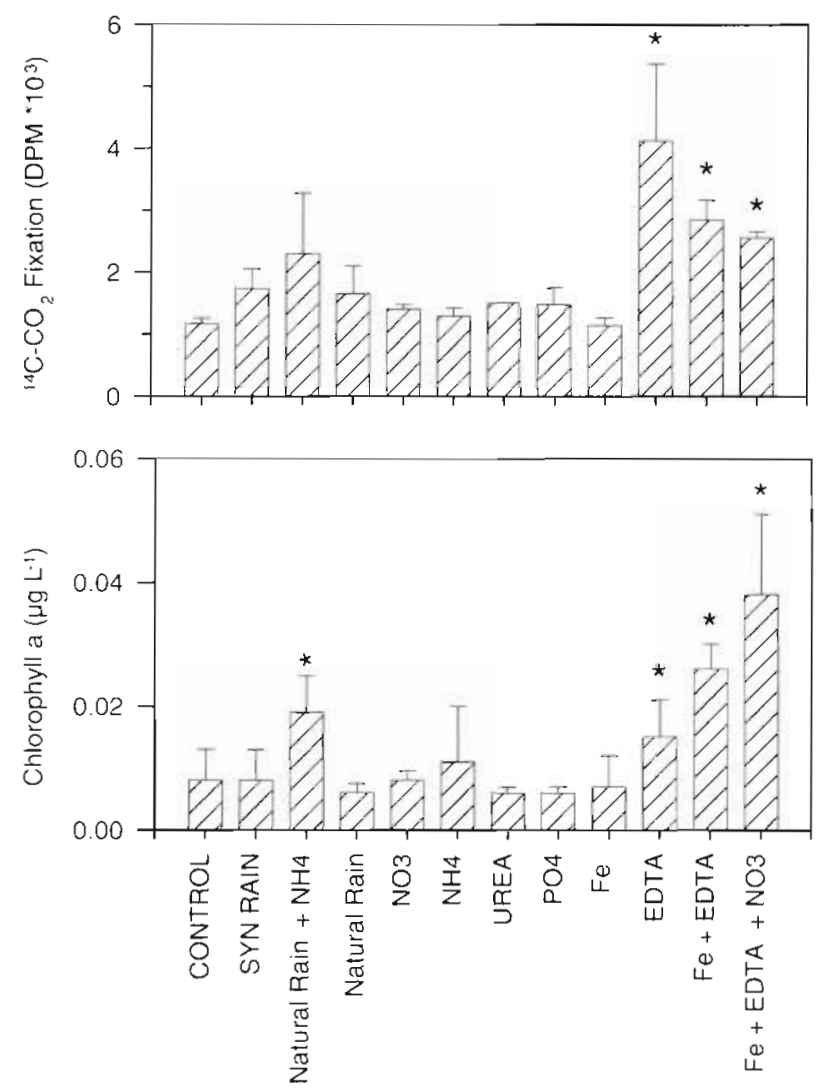

Fig. 4. Phytoplankton ${ }^{14} \mathrm{CO}_{2}$ fixation (upper panel) and chl a responses (lower panel) to nutrient, synthetic and natural rain additions at the Gulf Stream location in May 1994. The final DIN concentration after natural rain addition was $2.8 \mu \mathrm{M}$, while the high $\mathrm{NH}_{4}{ }^{+}$addition yielded $4.5 \mu \mathrm{M}$ N. Bioassays were incubated for $2 \mathrm{~d}$

productivity, especially at the more offshore Gulf Stream and Sargasso Sea locations (Table 2). When combined, $\mathrm{FeCl}_{3}+\mathrm{EDTA}+\mathrm{NO}_{3}{ }^{-}$often exceeded stimulation observed by either $\mathrm{FeCl}_{3}+$ EDTA or $\mathrm{NO}_{3}{ }^{-}$alone (Fig. 5). Overall, $\mathrm{FeCl}_{3}+$ EDTA together with $\mathrm{NO}_{3}{ }^{-}$ stimulated productivity (as either ${ }^{14} \mathrm{CO}_{2}$ fixation or chl a) in 12 of the 13 bioassays (Table 2). Synergistic Fe- $\mathrm{NO}_{3}{ }^{-}$stimulation was most significant at the offshore locations throughout the sampling period (Table 2).

Urea additions proved significantly stimulatory in 3 of 12 bioassays (May 1994 and September 1995) at the inner shelf location, while offshore (Gulf Stream) stimulation was noted only once during September 1995 (Table 2).

Phosphate additions were not significantly stimulatory (Table 2, Figs. 2-5). This indicated that $\mathrm{P}$ supplies were adequate at all locations at any time, confirming previous nutrient limitation studies in these waters (Thayer 1974, Paerl 1985, Paerl et al. 1990, Rudek et al. 1991).

\section{DISCUSSION}

In this study, we evaluated parallel responses of both photosynthetic $\mathrm{CO}_{2}$ fixation and phytoplankton chl a content to rainfall additions and to individual and combined nutrient enrichment. This enabled us to examine and evaluate the degree of agreement among these commonly used individual indicators of phytoplankton community responses to nutrient enrichment in space and time ${ }^{14} \mathrm{CO}_{2}$ fixation and chl a showed similar, but not identical, responses to nutrient and rainfall additions. There were notable discrepancies in terms of relative degrees and total magnitudes of stimulation and differences (based on statistical significance) between treatments and controls as well as among treatments. Both parameters are indicative of phytoplankton production responses; however, they reflect and integrate different physiological, biosynthetic and community structuring processes. The ${ }^{14} \mathrm{C}$ method measures cumulative net incorporation of ${ }^{14} \mathrm{CO}_{2}$ into particulate matter, initially mediated by photosynthesis. Net incorporation integrates photosynthetic activity, respiration, heterotrophic decomposition and graz-

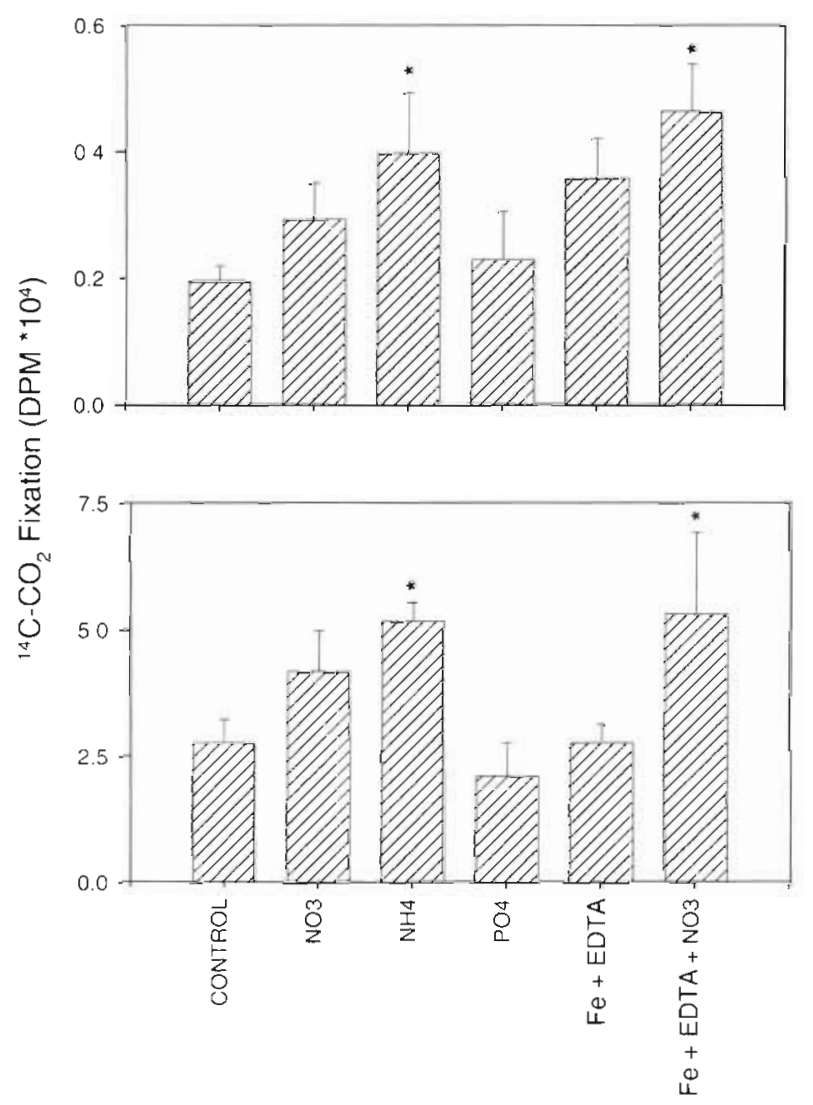

Fig. 5. Phytoplankton ${ }^{14} \mathrm{CO}_{2}$ fixation responses to nutrient additions in Gulf Stream (upper panel) and inner shelf (lower panel) Atlantic Ocean waters during September 1995. All bioassays were incubated for $3 \mathrm{~d}$ 
ing over the time of incubation. Earlier time-course bioassays (cf. Paerl et al. 1990, Rudek et al. 1991) showed variation in time-course slopes of net $\mathrm{CO}_{2}$ fixation within a 2 to $5 \mathrm{~d}$ incubation period, possibly indicative of differential interactions among these processes. The chl a method is an integrated measure of chl a synthesis versus degradation (death) and grazing In addition, different types and amounts of nutrient enrichment are known to have a selective effect on phytoplankton community size and composition (Stolte et al. 1994), which in turn could lead to diverging rates of ${ }^{14} \mathrm{CO}_{2}$ fixation and chl a synthesis. While this possibility was not investigated here, it has recently been verified for nearby North Carolina estuarine waters (Pinckney et al. 1998). We also observed differences in the degree to which a treatment differed from the control over time. For example, while the ${ }^{14} \mathrm{C}$ method always showed net ${ }^{14} \mathrm{C}$ incorporation during the incubation period for both controls and treatments, this was not always the case for chl a. Declines in chl a between the time of initiation and sampling of the bioassay could have been due to grazing, heterotrophic decomposition, altered turbulence and light regimes (cf. Paerl et al. 1990, Rudek at al. 1991, Willey \& Paerl 1993).

Although $N$ limitation was evident in near-and offshore waters, the forms in which $N$ was added as well as the medium in which it was administered (e.g. defined DIN sources, natural and synthetic rain) modulated the productivity response. The fact that $\mathrm{NH}_{4}{ }^{+}$ was, at times, more stimulatory than $\mathrm{NO}_{3}{ }^{-}$per amount of $\mathrm{N}$ administered suggests that $\mathrm{NO}_{3}{ }^{-}$reduction (i.e. nitrate reductase activity) was an important 'limiting' step controlling $\mathrm{N}$ assimilation and resultant growth stimulation of the phytoplankton community. Since FeEDTA additions enhanced the biostimulation observed with $\mathrm{NO}_{3}^{-}$(relative to $\mathrm{NH}_{4}^{+}$), we suspect that, when $\mathrm{NO}_{3}{ }^{-}$enrichment occurred, Fe availability may have controlled the magnitude of productivity stimulation.

Rain high in $\mathrm{NH}_{4}{ }^{+}$relative to $\mathrm{NO}_{3}{ }^{-}$was particularly effective at stimulating productivity (Figs. $2 \& 4$ ). This may be related to our observation that $\mathrm{NH}_{4}{ }^{+}$additions are capable of stimulating productivity independent of the Fe status of rain and receiving waters (i.e. since Fe is not required for assimilation of $\mathrm{NH}_{4}{ }^{+}$). On an annual basis, rainfall DIN at either Morehead City or Wilmington, $\mathrm{NC}$, is composed of approximately $65 \% \mathrm{NO}_{3}^{-}$ and $35 \% \mathrm{NH}_{4}{ }^{+}$(Willey et al. 1988, Paerl \& Fogel 1994). The dominant form of DIN deposited in adjacent Atlantic coastal waters may therefore be dependent on Fe availability in order to optimally support 'new' production.

In previous experimental work (Paerl et al. 1994) in these waters, EDTA (same source as used here) by itself frequently led to biostimulation, while Fe-EDTA led to the highest degree of stimulation (Paerl et al.
1994). This effect was also observed here, being most pronounced at the offshore Gulf Stream and Sargasso Sea locations (Table 2, Fig. 5).

Alternative explanations for these observations exist. EDTA may be enhancing nutrient trace metal availability by maintaining these metals in a dissolved form, counteracting potential losses from the water column by scavenging or precipitation. Since the enhancement was most pronounced in offshore waters, it would suggest that constraints on trace metal, specifically $\mathrm{Fe}$, availability are most severe in these waters. Because no large rivers discharge into this region, land-based inputs of $\mathrm{Fe}$ and potential natural organic chelators (e.g. humic and fulvic substances) ensuring Fe sufficiency are confined to the coastal inner shelf waters. As a result, EDTA and $\mathrm{FeCl}_{3}+$ EDTA additions frequently failed to lead to significant stimulation of production in these waters, while they did lead to stimulation in $\mathrm{Fe}$ - and/or chelator-devoid offshore waters. In addition, it has been suggested that EDTA stimulates productivity by chelating a potentially toxic metal (i.e. $\mathrm{Cu}$ ) and thereby minimizing its exposure to phytoplankton (Bruland et al. 1991). We previously (Paerl et al. 1994) tested this possibility by adding relatively large amounts $(0.1 \mu \mathrm{M})$ of $\mathrm{Cu}\left(\mathrm{as} \mathrm{CuSO}_{4}\right)$ in the presence and absence of EDTA and examining productivity responses. No significant EDTA effect was observed in either coastal or offshore waters, casting doubt on this possibility. We therefore suggest that EDTA acts as a true biostimulant, most likely by enhancing nutrient trace metal availability.

Trace metal determinations of oceanic rainfall suggest an approximately 2 -fold enrichment of Fe relative to crustal Al (Church et al. 1991). A large fraction (>80\%) of the $\mathrm{NO}_{3}^{-}$present in $\mathrm{AD}$ can be traced to human activities, including fossil fuel combustion and biomass burning (Briblecombe \& Stedman 1982, Galloway et al. 1994). These 2 nutrients are delivered together to surface seawater by $\mathrm{AD}$, and may at times function synergistically, stimulating primary production far more in combination than alone. The observed co-stimulatory impacts of $\mathrm{NO}_{3}^{-}$and $\mathrm{Fe}$ and possibly other metals in AD (Duce et al. 1991) have biogeochemical and trophic ramifications. A growing number of coastal and pelagic waters experiencing accelerating eutrophication are downwind of major anthropogenic sources of AD-N (Paerl 1988, 1995, 1997). These include (but are not limited to) the Baltic and North Seas (Boalch 1987, Smetacek et al. 1991, Riegman et al. 1992), the western Mediterranean Sea (Martin et al. 1989, Loye-Pilot et al. 1990), the western North Atlantic seaboard (Anderson 1989, 1995), the Yellow Sea (Zhang 1994) and the Sea of Japan (Hallegraeff 1993). With few exceptions, these waters have exhibited symptoms of eutrophication, including in- 
creases in frequencies and geographic expansions of potentially harmful toxic algal blooms, to expanding hypoxia and anoxia (Anderson 1989, 1995, Hallegraeff 1993, Paerl 1993, 1997).

Increasing anthropogenic nutrient impacts on coastal zone (and beyond) trophodynamics dictate the need for a detailed, comprehensive view of the composition and nature of accelerated nutrient loading as it pertains to chronic and acute biogeochemical and trophic impacts. While we have recognized enhanced $N$ loading as a key factor in coastal eutrophication, co-stimulatory interactions with other nutrients may modulate these impacts, thus altering production and food web dynamics. Iron has been implicated as such a modulator. Other trace metals (e.g. $\mathrm{Cu}, \mathrm{Zn}, \mathrm{Mn}, \mathrm{Pb}$, $\mathrm{Hg}, \mathrm{Mo}$, etc.) as well as organic $\mathrm{N}$ compounds resulting from industry, agriculture and urbanization require close scrutiny, for they could play additional, yet to be discovered roles in this regional and global process.

Acknowledgements. Research and logistic support were provided by the National Science Foundation, Projects OCE 9115706, DEB 9210495, and DEB 9220886, and the North Carolina Sea Grant Program (NOAA), Project RMER/30 and the U.S. EPA (project R82-5243-010). We thank the crew of the RV 'Cape Hatteras' for logistic support. Technical assistance was provided by H. Barnes, M. Fitzpatrick and C. Donahue. T Church, R. Barber, W. Sunda and K. Bruland provided valuable discussions, critiques and contributions during the course of manuscript preparation. We appreciate the thorough reviews of this manuscript provided by 3 anonymous individuals

\section{LITERATURE CITED}

Anderson DM (1989) Toxic algal blooms and red tides: a global perspective. In: Okaichi T, Anderson DM, Nemoto $T$ (eds) Red tides: biology, environmental science and toxicology. Elsevier, New York, p 11-17

Anderson DM (1995) Toxic red tides and harmful algal blooms: a practical challenge in coastal oceanography. Rev Geophys 33(Suppl):1189-1200

Behra P, Sigg L (1990) Evidence for redox cycling of iron in atmospheric water droplets. Nature 344:419-421

Boalch GJ (1987) Changes in the phytoplankton of the western English Channel in recent years. Br Phycol J 22: $225-235$

Briblecombe P, Stedman DH (1982) Historical evidence for a dramatic increase in the nitrate component of acid rain. Nature 298:460-462

Bruland KW, Donat JR, Hutchins DA (1991) Interactive influences of bioactive trace metals on biological production in oceanic waters. Limnol Oceanogr 36:1555-1577

Buijsman E, Maas HFM, Asman WAH (1987) Anthropogenic ammonia emissions in Europe. Atmos Environ 21: $1009-1020$

Church TM, Tramontano JM, Scudlark JR, Jickells TD, Tokos JJ, Knapp AH (1984) The wet deposition of trace metals to the western Atlantic Ocean at the mid-Atlantic coast and on Bermuda. Atmos Environ 18:2657-2664
Church TM, Tramontano JM, Whelpdale DM, Andreae MO, Galloway JN, Keene WC, Knapp AH, Tokos JJ (1991) Atmospheric and precipitation chemistry over the North Atlantic Ocean: shipboard results, April-May, 1984. J Geophys Res 96(D10): 18705-18725

Codispoti LA, Christensen J, Devol A, Paerl HW, Yoshinari T (in press) The influence of an unbalanced oceanic combined nitrogen budget on atmospheric carbon dioxide. Mar Chem

Copeland BJ, Gray J (1991) Status and trends report of the Albemarle-Pamlico estuarine study. NC Dept Nat Resources \& Community Dev Public, 90-01, Raleigh, NC

Cornell S, Rendell A, Jickells T (1995) Atmospheric inputs of dissolved organic nitrogen to the oceans. Nature 376 243-246

DiTullio GR, Hutchins DA, Bruland KW (1993) Interaction of iron and major nutrients controls phytoplankton growth and species composition in the tropical North Pacific Ocean. Limnol Oceanogr 38:495-508

Duce RA (1986) The impact of atmospheric nitrogen, phosphorus, and iron species on marine biological productivity. In: Buat-Menard $P$ (ed) The role of air-sea exchange in geochemical cycling. D Reidel, Norwell, MA, p 497-529

Duce RA, Tindale NW (1991) Atmospheric transport of iron and its deposition in the ocean. Limnol Oceanogr 36: $1715-1726$

Duce RA, Liss PS, Merrill JT, Atlas EL, Buat-Menard P, Hicks BB, Miller JM, Prospero JM, Arimoto R, Church TM, Ellis W, Galloway JN, Hansen L, Jickells TD, Knapp AH, Reinhardt KH, Schneider B, Soudine A, Tokos JJ, Tsunogai S, Wollast $R$, Zhou $M$ (1991) The atmospheric input of trace species to the world ocean. Global Biogeochem Cycles 5:193-259

Dugdale RC (1967) Nutrient limitation in the seas: dynamics, identification, and significance. Limnol Oceanogr 12: $685-695$

Fogel ML, Aguilar C, Cuhel R. Hollander DJ, Willey JD, Paerl HW (in press) Biological and isotopic changes in coastal waters induced by Hurricane Gordon. Limnol Oceanogr

Galloway JN, Levy H, Kasibahtla PS (1994) Year 2020: consequences of population growth and development on deposition of oxidized nitrogen. Ambio 23:120-123

Hallegraeff $G$ (1993) A review of harmful algal blooms and their apparent increase. Phycologia 32:79-99

Harrison WG, Platt T, Lewis MR (1987) F-ratio and its relationship to ambient nitrate concentration in coastal waters. J Plankton Res 9:235-245

Jickells I (1995) Atmospheric inputs of metals and nutrients to the oceans: their magnitude and effects. Mar Chem 48: $199-214$

Kennedy VS (1986) The estuary as a filter. Academic Press, New York

Loye-Pilot MD, Martin JM, Morelli J (1990) Atmospheric input of inorganic nitrogen to the western Mediterranean. Biogeochemistry 9:117-134

Martin JH, Gordon RM, Fitzwater SE (1991) The case for iron. Limnol Oceanogr 36(8):1793-1802

Martin JH, Coale KH, Johnson KS, Fitzwater SE, Gordon RM, Tanner SJ, Hunter CN, Elrod VA, Nowicki JL, Coley JL, Barber RT, Lindley S, Watson AJ, Van Scoy K, Law CS, Liddicoat MI, Ling R, Stanton T, Stockel J, Collins C, Anderson A, Bidigare R, Ondrusek M, Latasa M, Millero FJ, Lee K, Yao W, Zhang J, Friederich G, Sakamoto C, Chavez F, Buck K, Kolber Z, Greene R, Falkowski P, Chisholm SW, Hoge F, Swift R, Yungel J, Turner S, Nightingale P, Hatton A, Liss P, Tindale NW (1994) Testing the iron hypothesis in ecosystems of the equatorial Pacific Ocean. Nature 371:123-129 
Martın JM, Elbaz-Poulichet F, Gwue C, Loye-Pilot MD, Han $G$ (1989) River versus atmospheric input of material to the Mediterranean Sea: an overview. Mar Chem 28:159-182

Mopper K, Zika RG (1987) Free amino acids in marine rains: evidence for oxidation and potential role in nitrogen cycling. Nature 325:246-249

Nixon SW (1986) Nutrient dynamics and the productivity of marine coastal waters. In: Halwagy $R$, Clayton D, Behbehani $M$ (eds) Coastal eutrophication. The Alden Press, Oxford, $p$ 97-115

Paerl HW (1985) Enhancement of marine primary production by nitrogen-enriched acid rain. Nature 315:747-749

Paerl HW (1987) Dynamics of blue-green algal (microcystis) blooms in the lower Neuse River, North Carolina: causative factors and potential controls. Report No. 229 University of North Carolina Water Resources Research Institute, Raleigh

Paerl HW (1988) Nuisance phytoplankton blooms in coastal estuarine and inland waters. Limnol Oceanogr 33:823-847

Paerl HW (1993) Emerging role of atmospheric nitrogen deposition in coastal eutrophication: biogeochemical and trophic perspectives. Can J Fish Aquat Sci 50:2254-2269

Paerl HW (1995) Coastal eutrophication in relation to atmospheric nitrogen deposition: current perspectives. Ophelia $41: 237-259$

Paerl HW (1997) Coastal eutrophication and harmful algal blooms: importance of atmospheric deposition and groundwater as 'new' nitrogen and other nutrient sources. Limnol Oceanogr 42:1154-1165

Paerl HW, Fogel ML (1994) Isotopic characterization of atmospheric nilrogern inpuls as sources of enhanced prinlary production in coastal Atlantic Ocean waters. Mar Biol 119. $635-645$

Paerl HW, Rudek J, Mallin MA (1990) Stimulation of phytoplankton production in coastal waters by natural rainfall inputs: nutritional and trophic implications. Mar Biol 107: $247-254$

Paerl HW, Prufert-Bebout LE, Guo C (1994) Iron-stimulated $\mathrm{N}_{2}$ fixation and growth in natural and cultured populations of the planktonic marine cyanobacteria Trichodesmium spp. Appl Environ Microbiol 60:1044-1047

Peierls BL, Paerl HW (1997) The bioavailability of atmospheric organic nitrogen deposition to coastal phytoplankton. Limnol Oceanogr 42:1819-1823

Pinckney JL, Paerl HW, Harrington MB, Howe KE (1998) Annual cycles of phytoplankton community structure and bloom dynamics in the Neuse River Estuary, NC (USA). Mar Biol 131:371-381

Powell RT, King DW, Landing WM (1995) Iron distributions in the surface waters of the south Atlantic. Mar Chem 50: $13-20$

Prado-Fiedler R (1990) Atmospheric input of inorganic nitrogen species to the Kiel Bight. Helgoländer Meeresunters 44:21-30

Rjegman R, Noordeloos AAM, Cadee G (1992) Phaeocystis blooms and eutrophication of the continental coastal zones of the North Sea. Mar Biol 112:479-484

Rodhe H, Rood JM (1986) Temporal evolution of nitrogen

Editorial responsibility: Fereidoun Rassoulzadegan

(Contributing Editor), Villefranche-sur-Mer, France compounds in Swedish precipitation since 1955. Nature 321:762-764

Rudek J, Paerl HW, Mallin MA, Bates PW (1991) Seasonal and hydrological control of phytoplankton nutrient limitation in the lower Neuse River estuary, North Carolina. Mar Ecol Prog Ser 75:133-142

Ryther JH, Dunstan WM (1971) Nitrogen, phosphorus and eutrophication in the coastal marine environment. Science $171: 1008-1112$

Smetacek V, Bathmann U, Nöthig EM, Scharek R (1991) Coastal eutrophication: causes and consequences. In: Mantoura RCF, Martin JM, Wollast R (eds) Ocean margin processes in global change. John Wiley \& Sons, Chichester, p 251-279

Spokes LJ, Jickells TD, Lim B (1994) Solubilisation of aerosol trace metals by cloud processing: a laboratory study. Geochim Cosmochim Acta 58: 3281-3287

Stewart WDP (1974) Algal physiology and biochemistry. Blackwell, Oxford

Stolte W, McCollin T, Noordeloos AM, Riegman R (1994) Effect of nitrogen source on the size distribution within marine phytoplankton populations. J Exp Mar Biol ECol 184:83-97

Strickland JDH, Parsons TR (1972) A practical handbook of seawater analysis. Fish Res Bd Can Bull 167

Takeda S, Kamatani A, Kawanobe K (1995) Effects of nitrogen and iron enrichments on phytoplankton communities in the northwestern Indian Ocean. Mar Chem 50: $229-241$

Thayer GW (1974) Identity and regulation of nutrients limiting phyloplanklon production in the shallow estuaries near Beaufort, NC. Oecologia 14:75-92

Timperley $\mathrm{MH}$, Vigor-Brown RJ, Kawashima $\mathrm{M}$, Ishigami $\mathrm{M}$ (1985) Organic nitrogen compounds in atmospheric precipitation: their chemistry and availability to phytoplankton. Can J Fish Aquat Sci 42:1171-1177

Willey JD, Cahoon LB (1991) Enhancement of chlorophyll a production in Gulf Stream surface seawater by rainwater nitrate. Mar Chem 34:63-75

Willey JD, Paerl HW (1993) Enhancement of chlorophyll a production in Gulf Stream surface seawater by synthetic versus natural rain. Mar Biol 116:329-334

Willey JD, Bennett RI, Wiliams JM, Denne RK, Kornegay CR, Perlotto MS, Moore BM (1988) Effect of storm type on rainwater composition in southeastern North Carolina. Environ Sci Technol 22:41-46

Wollast R (1991) The coastal organic carbon cycle: fluxes, sources, and sinks. In: Mantoura RCF, Martin JM, Wollast $R$ (eds) Ocean margin processes in global change. John Wiley \& Sons. Chichester, p 365-382

Zhang J (1994) Atmospheric wet deposition of nutrient elements: correlation with harmful biological blooms in Northwest Pacific coastal zones. Ambio 23:464-468

Zhuang G, Yi Z, Duce RA (1992) Chemistry of iron in marine aerosols. Global Biogeochem Cycles 6(2):161-173

Zhuang G, Yi Z, Wallace GT (1995) Iron(II) in rainwater, snow, and surface seawater from a coastal environment. Mar Chem 50.41-50

Submitted: April 20, 1998; Accepted: August 31, 1998

Proots received from author(s): December 29, 1998 